\title{
MIGRATION PATTERNS IN EASTERN EUROPE AND THE WORLD: A GRAVITY APPROACH
}

Elliott Parker

\begin{abstract}
This study uses a UN dataset of foreign-born residents in and from 154 different countries, available every fifth year since 1990, to estimate an augmented gravity model for Eastern Europe and the world. Migration responds to higher incomes in the host country, though the effect diminishes with income. Unlike the rest of the world, East European migration increases with the exchange rate in the host and higher incomes in the origin, but not with political autocracy or conflict in the origin country. Controlling for these differences, Eastern Europe has fewer immigrants and emigrants than the model would otherwise predict.
\end{abstract}

Keywords: immigration, gravity model, Eastern Europe

JEL Code: F22, F66

\section{INTRODUCTION}

Does Eastern Europe have an immigration problem? The Gallup World Poll reported that nine of the ten countries that were least accepting of immigrants (out of 138 countries surveyed) were located in Eastern Europe (Esipova, Pugliese, and Ray 2018). A recent Pew Global Attitudes Survey found that immigration is unpopular in many countries: on average for 27 countries surveyed, $45 \%$ of respondents opposed immigration while only $14 \%$ supported it (Connor and Krogstad 2018). The opposition in Eastern Europe was even greater, however. Respondents in Hungary were $72 \%$ opposed compared to only $2 \%$ in support. In Poland, respondents were $49 \%$ opposed compared to $9 \%$ in support. Russian respondents were $67 \%$ opposed compared to only $7 \%$ who supported immigration.

Górak-Sosnowska and Pachocka (2019) report from another survey in 2017 that over half of Poles were willing to exit the EU if that was the cost of preventing more refugees from Islamic countries. Poland's
Law and Justice Party (PiS) won national elections in 2015 with anti-immigrant rhetoric; during the 2015 campaign its party leader, Jarosław Kaczyński, said that Muslim refugees carry "parasites and protozoa" (Chapman 2019).

Hungary's Fidesz Party has kept control of the government since 2010 largely by focusing on antiimmigrant policies, and the current COVID-19 pandemic appears to be substantially strengthening this control. Immigrants in Hungary are made to feel "very

\footnotetext{
Elliott Parker, PhD

Professor and Chair

Department of Economics

University of Nevada, Reno

E-mail: eparker@unr.edu

Address: 1664 N. Virginia Street

Reno, NV 89557 USA
} 
unwelcome" (Barry 2019). Viktor Orbán, Hungary's prime minister, advocates "procreation, not immigration" as his strategy for addressing Hungary's declining population (Walker 2019).

Migration estimates by the United Nations tell a somewhat different story (UN 2017). Table 1 reports the share of foreign-born residents either in or from Eastern Europe (EE), which is defined here as 20 former socialist countries of Europe. This includes four members of the Visegrád Group (Poland, Czechia, Slovakia, and Hungary), six republics of the former Yugoslavia (Serbia, Croatia, Bosnia \& Herzegovina, Slovenia, North Macedonia, and Montenegro), three other southeast European countries (Romania, Bulgaria, and Albania), and seven former Soviet Republics (Russia, Ukraine, Belarus, Moldova, Lithuania, Latvia, and Estonia).
Ten of these states are members of the EU, including the Visegrád Four and the Baltic Three, and eight are members of the Schengen Area. Data for Kosovo are not reported separately.

The share of foreign-born residents in the EE region is higher than for the world on average, but less than in Western Europe or the United States. In most of the region birthrates are low and population growth is either slow or declining. Overall, immigration has been relatively stable in the region since 1990, at just over $6 \%$ of the total population.

The immigrant share for both Serbia and Croatia jumped significantly between 1990 and 2000, and the share for Montenegro jumped significantly from 2000 to 2010 . Presumably, these shifts were caused by the breakup of the former Yugoslavia. Otherwise, the

Table 1. UN Migration Rates for Eastern Europe

\begin{tabular}{|c|c|c|c|c|c|c|c|c|c|c|}
\hline \multirow[b]{3}{*}{ Region/ Country } & \multicolumn{2}{|c|}{ Population } & \multicolumn{8}{|c|}{ Foreign-Born Residents (Percent) } \\
\hline & \multirow{2}{*}{$\begin{array}{l}\text { Mill. } \\
2017\end{array}$} & \multirow{2}{*}{$\begin{array}{c}\text { Growth } \\
\text { Avg. \% } \\
\text { 1990-2017 }\end{array}$} & \multicolumn{4}{|c|}{ Immigrants } & \multicolumn{4}{|c|}{ Emigrants } \\
\hline & & & 1990 & 2000 & 2010 & 2017 & 1990 & 2000 & 2010 & 2017 \\
\hline Eastern Europe (EE) & 321.1 & -0.2 & 6.4 & 6.1 & 5.9 & 6.3 & 8.1 & 8.8 & 10.5 & 11.6 \\
\hline Visegrad Four: & 63.8 & 0.0 & 2.5 & 2.3 & 2.5 & 2.8 & 3.6 & 4.9 & 8.6 & 10.4 \\
\hline Poland & 38 & 0.0 & 3.0 & 2.2 & 1.7 & 1.7 & 4.0 & 5.4 & 10.1 & 12.4 \\
\hline Hungary & 9.8 & -0.2 & 3.3 & 2.9 & 4.4 & 5.1 & 3.7 & 4.1 & 5.3 & 6.5 \\
\hline Czechia & 10.6 & 0.1 & 1.1 & 2.2 & 3.8 & 4.1 & 2.7 & 3.9 & 7.6 & 9.1 \\
\hline Slovakia & 5.4 & 0.1 & 0.8 & 2.2 & 2.7 & 3.4 & 2.5 & 4.7 & 5.5 & 6.6 \\
\hline Former Yugoslavia: & 19.3 & -0.4 & 4.2 & 8.9 & 9.5 & 9.6 & 12.1 & 21.2 & 20.0 & 22.6 \\
\hline Serbia & 7 & -0.3 & 1.3 & 11.4 & 11.3 & 11.4 & 9.3 & 15.1 & 11.6 & 13.6 \\
\hline Croatia & 4.1 & -0.5 & 10.0 & 13.1 & 13.3 & 13.6 & 8.9 & 19.6 & 20.1 & 22.2 \\
\hline Bosnia \& Herzegovina & 3.4 & -1.1 & 1.3 & 2.2 & 1.0 & 1.1 & 19.3 & 39.2 & 42.5 & 49.5 \\
\hline Slovenia & 2.1 & 0.1 & 8.9 & 8.6 & 12.4 & 11.8 & 4.6 & 6.0 & 6.1 & 6.9 \\
\hline North Macedonia & 2.1 & 0.2 & 4.8 & 6.2 & 6.3 & 6.3 & 21.5 & 26.1 & 22.5 & 25.7 \\
\hline Montenegro & 0.6 & 0.1 & 0.0 & 0.0 & 12.7 & 11.4 & 13.0 & 29.9 & 21.2 & 22.1 \\
\hline Other SE Europe: & 29.5 & 0.0 & 0.6 & 0.7 & 1.0 & 2.0 & 4.6 & 7.9 & 18.1 & 20.4 \\
\hline Romania & 19.6 & -0.6 & 0.6 & 0.6 & 0.8 & 1.9 & 3.5 & 5.1 & 16.2 & 18.3 \\
\hline Bulgaria & 7.1 & -0.8 & 0.2 & 0.5 & 1.0 & 2.2 & 7.1 & 8.5 & 15.2 & 18.3 \\
\hline Albania & 2.9 & -0.5 & 2.0 & 2.5 & 1.8 & 1.8 & 5.5 & 26.7 & 38.8 & 40.0 \\
\hline Former Soviet EE: & 208.5 & -0.2 & 9.6 & 9.0 & 8.6 & 8.9 & 9.5 & 8.8 & 9.0 & 9.7 \\
\hline Russia & 144.5 & -0.1 & 7.8 & 8.1 & 7.8 & 8.1 & 8.5 & 7.3 & 7.1 & 7.4 \\
\hline Ukraine & 44.8 & -0.5 & 13.3 & 11.2 & 10.5 & 11.1 & 10.7 & 11.4 & 11.9 & 13.3 \\
\hline Belarus & 9.5 & -0.3 & 12.3 & 11.3 & 11.5 & 11.4 & 17.4 & 16.9 & 15.5 & 15.6 \\
\hline Moldova & 3.5 & -0.1 & 14.7 & 6.8 & 4.4 & 3.9 & 16.9 & 16.5 & 23.4 & 27.4 \\
\hline Lithuania & 2.8 & -1.0 & 9.4 & 6.1 & 5.2 & 4.4 & 9.2 & 10.0 & 15.6 & 21.1 \\
\hline Latvia & 1.9 & -1.2 & 24.3 & 18.2 & 15.0 & 13.2 & 8.1 & 10.1 & 14.6 & 19.3 \\
\hline Estonia & 1.3 & -0.6 & 24.3 & 17.9 & 16.4 & 14.6 & 7.3 & 10.2 & 12.2 & 15.1 \\
\hline Other Europe & 422.9 & 0.4 & 7.2 & 9.2 & 12.5 & 13.7 & 5.3 & 5.2 & 5.2 & 5.7 \\
\hline Total Europe & 743.9 & 0.1 & 6.8 & 7.8 & 9.6 & 10.5 & 6.6 & 6.8 & 7.5 & 8.2 \\
\hline
\end{tabular}


immigrant share since 2000 only rose by $2 \%$ or more in Slovenia and Hungary (though for reasons explained below the 2017 estimate for Poland may be significantly underestimated). In comparison, the immigrant share for the rest of Europe has risen much faster, by $4.5 \%$ since 2000 .

Emigration from the EE region is almost twice as much as its immigration. Since 2000 , roughly nine million East Europeans have emigrated, and the share of population living in other countries has increased the most for Albania (13\%), Romania (13\%), Lithuania (11\%), Moldova (11\%), Bosnia \& Herzegovina (10\%), Bulgaria (10\%), Latvia (9\%), Poland (7\%), Czechia (5\%), and Estonia (5\%). This emigration accounts for a significant portion of the immigration into the rest of Europe. Though remittances from emigrants can be significant, emigration is also unpopular: The Pew Survey reports that $80 \%$ oppose emigration in Hungary, $68 \%$ oppose it in Poland, and $71 \%$ oppose it in Russia (Connor and Krogstad 2018).

This study estimates an augmented gravity model to examine Eastern Europe's immigration and emigration patterns relative to the rest of the world. We are unable to find other studies that have made a similar comparison. Holding everything else constant, Eastern Europe has less migration, both in and out, than the rest of the world. Shared EU membership made this migration more likely, while shared membership in the Schengen Agreement made it less likely. We also find evidence suggesting that East European migrants are less likely to come from poorer countries, and more likely to be attracted by an overvalued currency, suggesting perhaps an intention to repatriate migrant earnings through remittances or return migration.

\section{MIGRATION DATA}

The United Nations collects data on population and immigration from national statistical offices and provides intercensal estimates of foreign-born migrants in and from 231 countries (UN 2017). These data are available for every five years from 1990 to 2015, with more recent estimates available for 2017 and 2019. Because it uses intercensal estimates, which are often on a decennial schedule, the most recent UN data may not capture changes in trend that occurred after the last census.

According to these UN estimates, only 3.5\% of the world's population was born in a country they currently do not reside in. This has risen from $2.9 \%$ in 1990. The world's largest current diaspora originates from India, with 17.5 million living emigrants, followed by those born in Mexico (11.8 million), China (10.7 million), Russia (10.6 million), and Syria (8.3 million). By region, the largest group of foreign-born residents are those born in and still residing within Asia (66.8 million), followed by those born in Latin America but living in North America (26.6 million), those who have migrated within Africa (21.2 million), those who moved from Asia to North America (17.5 million), and those who left Eastern Europe for the rest of Europe (15.1 million). Table 2 shows these UN estimates of foreign-born residents for 2019 , by host region and origin.

The largest host country for immigrants is the United States, often called "a nation of immigrants" (Kennedy 1959). The US hosts over 50 million foreignborn residents, and immigrants are $15.4 \%$ of its total population, up from $9.3 \%$ in 1990 . This is still a smaller share than in 65 other countries, and a smaller share than many Americans believe, but still a significant

Table 2. Foreign-born Residents in 2019 , by Region (thousands)

\begin{tabular}{|c|c|c|c|c|c|c|c|c|}
\hline \multirow[b]{2}{*}{ Host/ Region } & \multicolumn{8}{|c|}{ Region of Origin } \\
\hline & $\begin{array}{c}\text { East } \\
\text { Europe }\end{array}$ & $\begin{array}{l}\text { Other } \\
\text { Europe }\end{array}$ & $\begin{array}{c}\text { North } \\
\text { America }\end{array}$ & $\begin{array}{c}\text { Latin } \\
\text { America }\end{array}$ & Asia & Africa & $\begin{array}{l}\text { Oceania } \\
\text { \& Other }\end{array}$ & $\begin{array}{l}\text { World } \\
\text { Total }\end{array}$ \\
\hline East Europe & 13,025 & 918 & 68 & 20 & 8,050 & 96 & 525 & 22,702 \\
\hline Other Europe & 15,129 & 12,792 & 1,029 & 4,958 & 14,154 & 10,488 & 1053 & 59,603 \\
\hline Nor.America & 2,552 & 4,341 & 1,375 & 26,580 & 17,458 & 3,225 & 3118 & 58,648 \\
\hline Lat. America & 80 & 1,338 & 1,243 & 8,243 & 409 & 40 & 320 & 11,673 \\
\hline Asia & 5,973 & 1,160 & 514 & 425 & 66,758 & 4,586 & 4144 & 83,559 \\
\hline Africa & 86 & 818 & 67 & 38 & 1,231 & 21,210 & 3080 & 26,529 \\
\hline Oceania & 404 & 2,489 & 233 & 201 & 3,816 & 562 & 1,222 & 8,928 \\
\hline World Total & 37,248 & 23,855 & 4,529 & 40,463 & 111,876 & 40,207 & 13,463 & 271,642 \\
\hline
\end{tabular}


number. Roughly 11.4 million US residents were born in Mexico, followed by 10.7 million US residents born in China, 2.7 million born in India, and 2 million born in the Philippines. In fact, the largest country-to-country migrant group in the world is Mexican-born US residents.

The election of Donald Trump in the United States in 2016 was in part driven by a political backlash against immigrants, and "Build the Wall" was a popular chant at Trump's rallies. A study by Mayda, Peri, and Steingress (2018) suggests that differences in the relative skills of US immigrants contributed to increased polarization in U.S. elections from 1990 to 2010, as regions that received the largest influx of unskilled immigrants voted significantly more Republican, while regions that received more skilled immigrants voted increasingly Democratic.
Table 3 shows the UN data by regions and subregions of the world, relative to population. Like the rest of Oceania, Australia and New Zealand host the largest percentages of foreign-born residents, followed by Western Asia, North America, and Western Europe. Polynesia, the Caribbean, and Eastern Europe have the largest shares of emigrants, at least as a share of population.

Europe has also received a higher share of immigrants, as its share of foreign-born residents has risen from $6.8 \%$ to $11.0 \%$ over the past three decades. In ten European countries surveyed, an average of 51\% of respondents wanted less immigration, while only $10 \%$ wanted more immigration (Connor and Krogstad 2018). In much of Europe, the political effects have been profound. News sources have linked the rise of Euro-skepticism to anti-immigrant views, and the

Table 3. Host and Origins by Sub-Region, 2019

\begin{tabular}{|c|c|c|c|c|c|}
\hline Region & Population & Host & Percent & Origin & Percent \\
\hline Eastern Europe & 293,445 & 20,279 & 6.9 & 30,730 & 10.5 \\
\hline Northern Europe & 105,769 & 15,095 & 14.3 & 7,899 & 7.5 \\
\hline Southern Europe & 152,447 & 16,504 & 10.8 & 13,600 & 8.9 \\
\hline Western Europe & 195,522 & 30,427 & 15.6 & 9,261 & 4.7 \\
\hline North America & 366,601 & 58,648 & 16.0 & 4,268 & 1.2 \\
\hline Caribbean & 43,310 & 1,525 & 3.5 & 8,915 & 20.6 \\
\hline Central America & 177,587 & 1,928 & 1.1 & 16,478 & 9.3 \\
\hline South America & 427,191 & 8,221 & 1.9 & 14,479 & 3.4 \\
\hline Central Asia & 73,212 & 5,543 & 7.6 & 7,569 & 10.3 \\
\hline Eastern Asia & $1,648,837$ & 8,106 & 0.5 & 15,341 & 0.9 \\
\hline South-Eastern Asia & 661,424 & 10,191 & 1.5 & 22,639 & 3.4 \\
\hline Southern Asia & $1,918,211$ & 14,084 & 0.7 & 42,531 & 2.2 \\
\hline Western Asia & 275,306 & 45,636 & 16.6 & 24,832 & 9.0 \\
\hline Eastern Africa & 433,168 & 7,908 & 1.8 & 12,146 & 2.8 \\
\hline Middle Africa & 174,308 & 3,785 & 2.2 & 4,152 & 2.4 \\
\hline Northern Africa & 241,781 & 2,956 & 1.2 & 11,878 & 4.9 \\
\hline Southern Africa & 66,630 & 4,482 & 6.7 & 1,584 & 2.4 \\
\hline Western Africa & 389,856 & 7,398 & 1.9 & 10,092 & 2.6 \\
\hline Australia/N. Zealand & 29,986 & 8,618 & 28.7 & 1,365 & 4.6 \\
\hline Melanesia & 10,919 & 124 & 1.1 & 244 & 2.2 \\
\hline Micronesia & 542 & 118 & 21.7 & 44 & 8.2 \\
\hline Polynesia & 686 & 68 & 10.0 & 237 & 34.6 \\
\hline Unidentified Origin & & & & 11,358 & \\
\hline Total & $7,686,738$ & 271,642 & 3.5 & 271,642 & 3.5 \\
\hline Included & $7,639,353$ & 264,173 & 3.5 & 247,813 & 3.2 \\
\hline Excluded & 47,385 & 7,469 & 15.8 & 23,830 & 50.3 \\
\hline Percent Excluded & 0.6 & 2.7 & & 8.8 & \\
\hline
\end{tabular}


Schengen Agreement of passport-free travel within 26 member countries in Europe - not all of which are EU members - has apparently left some Europeans feeling that they have lost control of their borders.

A key issue in the "Brexit" vote to remove the United Kingdom from the European Union was the Syrian refugee crisis, and the fear that the UK might be flooded with immigrants if Turkey was ever allowed to join the EU. In France, Marine Le Pen, the daughter of National Front founder Jean-Marie Le Pen, reached the second round of presidential elections in 2017 largely on an anti-immigrant platform. Anti-immigrant parties have also increased their number of legislative seats in countries like Italy, Germany, Denmark, and Finland.

Table 4 shows specific data for Eastern Europe. The EE region has $4.2 \%$ of world population, mostly in Russia, Ukraine, and Poland, but more than $17 \%$ of the world's migrants either reside in or were born in Eastern Europe. As much as regional politics are driven by immigration, the region is a net exporter of people. Relative to current population, $6.9 \%$ of EE residents are foreign born and $10.5 \%$ of those born in the EE region are living elsewhere.

About 37 million people from EE countries live in another country, and only about 23 million EE residents are foreign-born. An estimated 13 million of these EE residents were born within the region, and half of these internal migrants are either Ukrainians in Russia or vice-versa (a flow of migrants largely driven by the recent conflict). As a result, about 10 million people residing in EE states were born outside of the region, while 24 million people born in the region reside outside of it, mostly in the rest of Europe. In the UN dataset, 34,458 pairs have either an EE host or origin, but $77 \%$ of these pairs have zero migrants.
Other than Russians in Ukraine and vice-versa, Poland has the most migrants in the region, and like the rest of the EE region it is a net exporter of people; an estimated 4.4 million Poles live elsewhere, especially in Germany, the United Kingdom, and the United States. Ukraine is a large source of Poland's immigrants, particularly after a Visa Facilitation Agreement was signed with the EU in 2007 and amended in 2013 (Pachocka 2016). According to the UN estimates, 656,000 Polish residents are foreign-born, with 414,000 from Ukraine and elsewhere in the region, and 242,000 from Germany and elsewhere.

Even as the Polish national government has opposed immigration, local governments dominated by the opposition in cities like Warsaw, Lublin, and Gdańsk have responded with projects to encourage it (White 2018). Poland has dramatically increased the number of immigrants admitted, albeit from nonMuslim countries. Eurostat (2019) reports that Poland issued 3.4 million new residence permits from 2010 to 2018 and surpassed the United Kingdom in 2016 to become the EU country granting the most permits. Roughly $90 \%$ of these permits were for work purposes, and $85 \%$ were issued to Ukrainians.

It is clear that this influx of Ukrainians represents a change in the trend. In 2010, for example, Poland only granted 102,000 permits, but by 2018635,000 permits were issued, a figure comparable to what the UN reports for the total number of foreign-born residents in Poland in 2019. Some researchers estimate that there are now up to 2 million Ukrainians in Poland (Santora 2019), not enough to make Poland a net importer of people but still a significant increase. As a result, recent UN estimates for Poland most likely underestimate its immigrants.

Table 4. Foreign-born Residents in 2019, Eastern Europe, by Country or Region (thousands)

\begin{tabular}{|c|c|c|c|c|c|c|c|c|c|c|c|}
\hline \multirow[b]{2}{*}{$\begin{array}{l}\text { Host Region/ } \\
\text { Country }\end{array}$} & \multicolumn{10}{|c|}{ Country or Region of Origin } & \multirow[b]{2}{*}{$\begin{array}{l}\text { World } \\
\text { Total }\end{array}$} \\
\hline & $\begin{array}{l}\text { East } \\
\text { Europe }\end{array}$ & Poland & Hungary & Czechia & Slovakia & $\begin{array}{l}\text { Former } \\
\text { Yugoslavia }\end{array}$ & $\begin{array}{l}\text { Other } \\
\text { SE Eur }\end{array}$ & $\begin{array}{l}\text { Former } \\
\text { Soviet EE }\end{array}$ & $\begin{array}{l}\text { Other } \\
\text { Europe }\end{array}$ & $\begin{array}{l}\text { Other } \\
\text { Regions }\end{array}$ & \\
\hline Eastern Europe & 13,025 & 71 & 50 & 111 & 129 & 1,616 & 356 & 10,693 & 918 & 8,759 & 22,702 \\
\hline Poland & 414 & & 1 & 5 & 1 & 6 & 5 & 395 & 191 & 52 & 656 \\
\hline Hungary & 339 & 3 & & 1 & 21 & 45 & 207 & 61 & 83 & 90 & 512 \\
\hline Czechia & 308 & 19 & 1 & & 99 & 9 & 19 & 161 & 41 & 164 & 513 \\
\hline Slovakia & 144 & 7 & 17 & 89 & & 5 & 12 & 15 & 31 & 13 & 188 \\
\hline Fmr Yugoslavia & 1,645 & 2 & 3 & 2 & 5 & 1,538 & 80 & 14 & 108 & 77 & 1,829 \\
\hline Other SE Europe & 292 & 3 & 9 & 2 & 1 & 10 & 18 & 249 & 263 & 124 & 680 \\
\hline Former Soviet EE & 9,883 & 36 & 18 & 12 & 2 & 2 & 15 & 9,798 & 202 & 8,239 & 18,324 \\
\hline Other Europe & 15,129 & 3,754 & 414 & 671 & 204 & 2,125 & 4,672 & 3,289 & 12,792 & 31,682 & 59,603 \\
\hline Other Regions & 9,094 & 623 & 168 & 130 & 13 & 811 & 1,294 & 6,056 & 10,145 & 170,098 & 189,338 \\
\hline World Total & 37,248 & 4,447 & 632 & 911 & 346 & 4,552 & 6,322 & 20,038 & 23,855 & 210,539 & 271,642 \\
\hline
\end{tabular}


Table 5. Foreign-born Residents, Former Yugoslavia, 2019 (thousands)

\begin{tabular}{|c|c|c|c|c|c|c|c|c|}
\hline \multirow[b]{2}{*}{$\begin{array}{l}\text { Host Country or } \\
\text { Region }\end{array}$} & \multicolumn{8}{|c|}{ Region of Origin } \\
\hline & Serbia & Croatia & $\begin{array}{c}\text { Bosnia \& } \\
\text { Herzegovina }\end{array}$ & Slovenia & $\begin{array}{c}\text { North } \\
\text { Macedonia }\end{array}$ & $\begin{array}{l}\text { Monte- } \\
\text { negro }\end{array}$ & $\begin{array}{l}\text { Rest } \\
\text { of EE }\end{array}$ & $\begin{array}{l}\text { Rest of } \\
\text { World }\end{array}$ \\
\hline Serbia & & 288 & 341 & 11 & 47 & 72 & 13 & 47 \\
\hline Croatia & 47 & & 374 & 18 & 9 & 6 & 6 & 58 \\
\hline Bosnia \& Herzegovina & 9 & 12 & & 2 & 3 & 4 & 4 & 2 \\
\hline Slovenia & 25 & 46 & 105 & & 17 & 3 & 9 & 49 \\
\hline North Macedonia & 18 & 1 & 9 & 0 & & 9 & 70 & 24 \\
\hline Montenegro & 9 & 16 & 32 & 2 & 3 & & 4 & 5 \\
\hline Rest of EE & 53 & 6 & 8 & 2 & 8 & 1 & 11,303 & 9,493 \\
\hline Rest of World & 790 & 621 & 784 & 113 & 571 & 58 & 21,286 & 224,717 \\
\hline
\end{tabular}

Most of the rest of migrants within the EE region are internal to the republics of the former Yugoslavia. Table 5 shows the UN's 2019 estimates of foreign-born residents, by origin and host, for the six republics of the former Yugoslavia, excluding Kosovo. Over 1.5 million residents in these republics are reported to be born elsewhere, but $85 \%$ of them were born in one of the other five republics, while over a third of all emigrants from the region currently live within the region. The largest numbers of foreign-born residents are individuals born in Bosnia but living in Croatia or Serbia, or individuals born in Serbia but living in Croatia. The big jump in migration occurred between 1990 and 1995 , presumably as a result of the Bosnian War of 1992-95. However, Efendic (2016) reports that almost half of the residents of Bosnia and Herzegovina still desire to emigrate, particularly the young and bettereducated. While economic factors matter, survey respondents report that the country's political situation matters more.

\section{CONCEPTUAL FRAMEWORK}

The UN (2017) dataset allows us to estimate the factors driving global immigration patterns. We begin with a gravity equation that explains migration as a function of the population of both host and origin countries, as well as the distance between them. This model allows us to identify key influences in order to better identify regional differences.

Zipf (1949) posited that human migration patterns should be consistent with the principle of least effort, as migrants will move to the nearest location that sufficiently improves their lives. Distance raises the cost of migration, production, and trade, and large populations will attract more migrants. The largest migrant flows will thus occur between population centers at the minimum distance possible. Sjaastad (1962) expressed migration incentives as an economic tradeoff between costs and benefits. The costs include transportation (particularly if migration is expected to be seasonal or temporary), the time needed for the employment search, and the psychic costs of separation from family, friends, language, and culture.

According to Sjaastad, the benefits of migration include increasing the migrant's money income, which will vary by occupation in a way that is not captured by average incomes, improving the migrant's safety and nonmonetary quality of life, and enriching opportunities for the migrant's children. Borjas (1989) refers to this migration as a human capital investment which depends on both estimated returns and costs. He develops a model of migration choice that predicts a higher emigration rate in response to a higher mean income in the host country, a lower mean income in the origin country, a lower cost of migration, and a greater reward in the host country for the migrant's specific demographic characteristics.

Franc, Časni, and Barišić (2019) studied the migration that resulted from the enlargement of the European Union, as citizens of Eastern Europe moved to Western Europe, and he framed migration as a result of both push and pull factors. He found that this migration rose from higher per-capita GDP in the host country, but also rose from higher income in the origin country. However, neither the differences in the unemployment rate nor in the youth unemployment rate was effective in explaining migration patterns.

One key issue is whether migration is temporary or permanent. Minelgaite, Christiansen, and Kristjánsdóttir (2019) reported on a survey of Lithuanian workers in Iceland, and found most of these relatively well-educated workers were working in temporary positions without expectation of permanent migration. In Kosovo, where almost a fifth of the 
population is estimated to be living abroad, Kotorri (2017) hypothesizes a nonlinear relationship between the probability that a migrant returns and the income they earn abroad, since the income effect might offset the substitution effect if reverse migration is a normal good. However, she does not find evidence for it. In some countries, the remittances sent home by migrants can account for a significant share of national income, and Loxha (2019) estimated that remittances from migrants considerably decreased the chances of poverty in Kosovar households that received them.

The Newtonian gravity equation was first applied by Tinbergen (1962) to estimate international trade volumes. Since Anderson (1979) and Bergstrand (1985), the bilateral gravity model for trade is usually estimated as a log-linear function of output, population, and distance, and has been used to explore the effects of exchange rate regimes (Thursby and Thursby 1987) and risk (Santana-Gallego and PérezRodriquez 2019), as well as many other things. For example, Luqman, Bikar, and Izraf (2016) used a gravity model to describe the patterns of trade resulting from the Economic Community of West African States (ECOWAS), while Head and Ries (1998) used an augmented gravity model to estimate the impact of immigration into Canada on its patterns of trade.

Poot et al. (2016) recently made the case that the gravity model has many uses in the study of migration. Crymble, Dennett, and Hitchcock (2018) used a gravity model approach to fit the reported internal migration of England's poorer classes into London during the late 18th century, while Kelly and O'Grada (2018) used it to fit reported origins of arrested radicals and sex workers in Paris for the 18th and 19th centuries. Using aggregate rather than bilateral immigration numbers, Lewer and Van den Berg (2008) rely on a gravity equation to model immigration for a time series of OECD countries, and the study includes the existing stock of immigrants as an explanatory factor.

Karemera, Oguledo, and Davis (2000) used the gravity equation to model immigration from 70 countries over 11 years, for both the U.S. and Canada, using nearest air distance, population, income, growth, unemployment, language, financial indicators, political instability, political rights, civil liberties, changes in immigration policy, and continent of origin. While many of these variables were found to have a statistically significant effect, the authors found that the population of the origin country was negatively correlated with immigration.

The gravity model has also been used to estimate the effect of factors explaining emigration from Tajikistan and Kyrgyzstan, and GDP per capita was found to have a significant effect (Sulaimanova and
Bostan 2014). Both countries are among the top recipients of migrant remittances, relative to their own GDP, and the study found a significant and positive effect for the relative value of the exchange rate in the host country.

The basic Newtonian gravity equation specifies migration $(M / G)$ as a positive function of population $(P O P)$ in both the host $(h)$ and origin (o) locations, and as a negative function of the distance (DIS) between them. Treating $e^{a}$ as the equivalent of the gravitational constant:

$M I G_{h, o}=e^{\alpha} \frac{P O P_{h}^{\beta_{1}} P O P_{o}^{\beta_{2}}}{D I S_{h, o}^{\gamma}}$.

Using logarithms and lagged population for time $t$ minus interval $n$, this can be written as:

$\ln M I G_{h, o, t}=\alpha+\beta_{1} \ln P O P_{h, t-n}$

$+\beta_{2} \ln P O P_{o, t-n}-\gamma \ln D I S_{h, o}$.

Migrants benefit from information and connections, so they are more likely to follow past migrants. Researchers have found that one of the best predictors of future migration is the number of past migrants. The model is thus adjusted to specify the net flow of migrants as a function of population, distance, and the lagged stock of migrants:

$\ln \Delta M I G_{h, o, t}=\alpha+\beta_{1} \ln P O P_{h, t-n}$

$+\beta_{2} \operatorname{lnPOP} P_{o, t-n}-\gamma \ln D I S_{h, o}+\rho \ln M I G_{h, o, t-n}$.

In this paper, distance is measured using a simple proxy, where $D I S=1$ if the two countries are neighbors or within the same subregion (e.g., Eastern Europe, Western Africa, South Asia); DIS = 2 if the countries are in different subregions yet share the same continent (e.g., Europe, Africa, Asia); DIS = 3 if the countries are on different continents yet both have access to seaports; and $D I S=4$ if the countries are on different continents and one or both are landlocked (e.g., Bolivia and Central Africa).

This simple gravity equation needs to be augmented because population and distance are not the only relevant factors. Migrants move for economic and political reasons, and this may make migration to more distant countries more desirable because those countries are more likely to have better economic prospects or more political stability. As a result, distance in an un-augmented model may have a positive effect 
instead of a negative effect. To augment this, the socalled "gravitational constant" is instead defined as a function of a vector $X$ of several political and economic variables that affect migration:

$$
\alpha=\alpha\left(X_{h, o, t-n}\right)=\alpha_{0}+\sum \alpha_{i} X_{i, h, o, t-n}
$$

The variables in the vector $X$ include shared variables, pull variables from the host country, and push variables from the origin country. Shared factors include dummy variables for EU membership and Schengen Area (SA) membership, as well as time increments to determine whether immigration is accelerating or not, holding everything else equal. EU membership makes internal immigration much easier, so we expect it will have a positive effect on immigration when membership is shared. SA membership reduces the need for formal changes of residence, so we expect it will have a negative effect when membership is shared.

For the host country, pull factors include its income per capita (INC) and a square term, reported in units of $\$ 10,000$ USD, adjusted for purchasing power parity. Richer countries should attract more migrants, but the relationship is unlikely to be linear. Pull factors also include the ratio of exchange rate overvaluation ratio $(E R)$, a dummy for EU membership, and the employment age ratio (EMP).

The cost of living can be considered a pull factor (Sjaastad 1962), but a response to exchange rate overvaluation yields some information about the expected direction of the flow of savings. If the host country has an overvalued currency, relative to the origin, this raises the value of the flow of savings from host to origin relative to the flow from origin to host. One can thus infer that the migrant intends either to send remittances back home or intends to bring savings back when he returns home. If migration is expected to be permanent, however, then the migrant is likely to bring savings from origin to host, making an overvalued currency in the host less desirable.

Presumably, EU membership makes a country a more attractive destination, while a higher employment age ratio could go either way, as it suggested more native supply of labor but also more opportunities. A positive coefficient for EE host countries would suggest they receive more immigrants than could be explained otherwise, even given potential under-reporting.

For the origin country, push factors also include its income per capita and its square. Poorer countries may be more likely to have more emigrants, but very poor migrants may be unable to afford the journey; as a results, the relationship for income may be nonlinear. In addition, push factors include a Polity Score $(P O L)$ and a variable for Conflict (CON). The Polity IV data set comes from the Center for Systemic Peace (Marshall and Gurr 2019) and reports a score between -10 (autocracy) and +10 (democracy) for 167 countries over the period 1800-2017. The Conflict index also comes from this source, using the Major Episodes of Political Violence database, and it ranges from 0 to 10.

Only 154 of the 231 countries in the UN dataset have data from the World Bank (2019) and the Center for Systemic Peace (Marshall and Gurr 2019), and the rest are excluded from the analysis. At the bottom of Table 3, the total population and number of migrants (by host and origin) were shown for the excluded countries, relative to the total. Excluded countries only account for $0.6 \%$ of the world population, and $2.7 \%$ of the host countries of immigrants. The number of emigrants from excluded origin countries is larger, at $8.8 \%$, mostly because the UN data does not identify the origin of all foreign-born residents, but also because excluded countries tend to have relatively more emigrants. After excluding countries with missing data, we still have more than 24,000 host-origin pairs for each year, and $78 \%$ of host-origin pairs have zero reported migrants. We also exclude data for 1990 in order to allow for lagged variables.

Table 6 reports the mean values of the variables used in the regression, by sample. These variables include $M I G$ and $\triangle M I G$, the number of foreign-born residents for a given host $h$ and origin $o$, as well as the change in that number; $D I S$, a proxy of the distance between host and origin; $P O P$, population in tens of millions; INC, real GDP per capita adjusted for purchasing power parity; $E R$, the exchange rate adjusted for purchasing-power-parity; $P O L$, a polity score ranging from autocracy to democracy; $C O N$, the score for political conflict or violence; $E M P$, the employment rate; $E U$, a dummy variable for EU membership; $S A$, a dummy variable for membership in the Schengen Area; and $E E$, a dummy variable for 20 East European countries.

The full sample contains 145,706 observations, but only 32,876 of these have positive values for both the number of foreign-born residents for a particular hostorigin pair, and the change in those residents over the last $n$ years. We can divide this selected sample into the first four five-year increments, from 1990 to 2010, and comparing it to the more recent increments of 2015 and 2017. The selected sample for Eastern Europe has 8,038 observations, including all instances in which either a host or origin country is one of the 20 East European countries. We report this for both the earlier and later time periods. 
Table 6. Mean Values of Variables by Sample

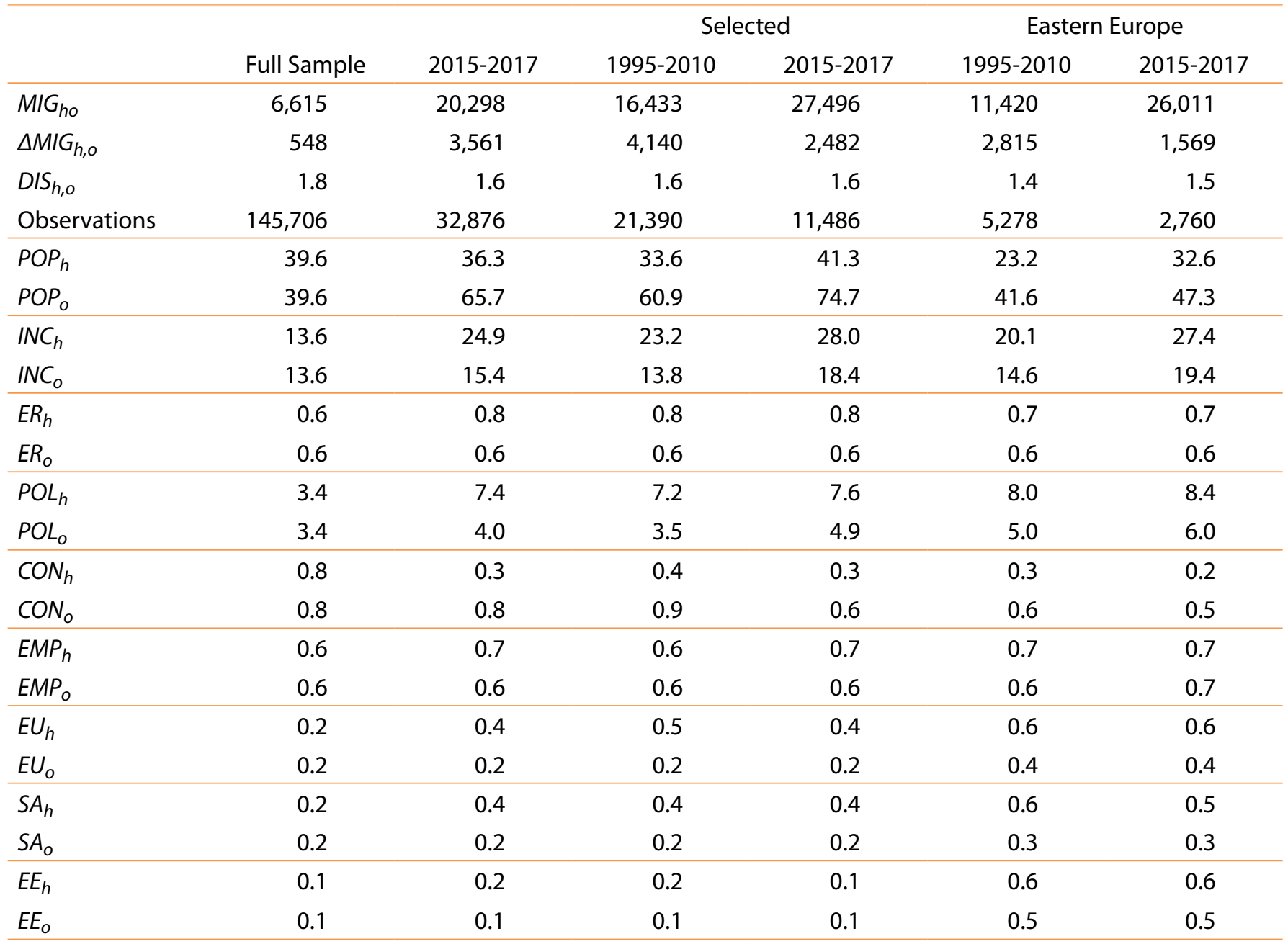

Once selected, differences emerge in the averages for host and origin countries. Relative to origin countries, host countries have smaller populations, higher income, a more valuable currency, a higher polity score (i.e., they are more democratic), less conflict, and a slightly higher employment rate. Host countries are also more likely to be in the EU and the SA, and are slightly more likely to be in Eastern Europe. Comparing the selected sample between the earlier and later time periods, population and income rose on average, the number of foreign-born residents increased, but the change in those residents between time periods declined. The last two columns, showing the earlier and later periods for the selected Eastern Europe sample, exhibit quantitative but not qualitative differences compared to the entire selected sample.

As noted above, bilateral immigration between any two countries is often zero, making logarithms undefined. One solution is to substitute very small numbers (i.e., 0.5) for zeroes so the logarithms are defined, while another is to aggregate the data into larger regions to eliminate zeroes. While we must exclude observations with missing data, further excluding observations with zero migrants from one country to another may create a selection bias. However, the Heckman (1979) selection procedure addresses the selection bias. A Probit regression is run on the selection decision using the same right-hand side variables. From this an inverse Mills ratio is calculated for each observation. The selected observations are then regressed on those same variables plus the inverse Mills ratio to remove the selection bias.

\section{RESULTS}

The above gravity model is estimated for 19952010, using the Heckman selection procedure. Four different regressions are reported. Column (1) of Table 7 shows the results for the simple gravity equation (3), with In $\Delta M I G_{h, o, t}$ being the left-hand side variable. We add dummy variables for East European host and origin countries. The results do not exhibit a good fit: while host and origin populations have the expected sign, distance appears to have a positive effect as explained above. Dummy variables for Eastern Europe 
Table 7. Migration Regressions for 1995-2010

Dependent Variable: $\ln \Delta M / G_{h, t-n}$

(2)

(3)

(4.a)

(4.b)

Variables

Simple

Augmented

EE Only

World

$\Delta \mathrm{EE}$

Gravity Variables:

\begin{tabular}{ll}
$\ln P O P_{h, t-n}$ & $0.018^{*}$ \\
$\ln P O P_{o, t-n}$ & $0.033^{* *}$ \\
$\ln D I S_{h, o}$ & $0.185^{* *}$ \\
$\ln M I G_{h, o, t-n}$ & $1.026^{* *}$ \\
\hline
\end{tabular}

$0.075 * *$
$0.085 * *$
$-0.337 * *$
$0.807 * *$

\begin{tabular}{|c|c|c|}
\hline 0.048 & ** & $0.066 * *$ \\
\hline 0.161 & ** & $0.080 * *$ \\
\hline-0.635 & $* *$ & $-0.313 * *$ \\
\hline 0.868 & $* *$ & 0.842 \\
\hline
\end{tabular}

Shared Variables:

$E U_{h, o}$
$S A_{h, o}$
$t>1995$
$t>2000$
$t>2005$

$\begin{array}{rr}0.321 * * & 0.232 * * \\ -0.195 * * & -0.129 * \\ -0.253 * * & -0.290 * * \\ 0.079 * * & 0.035 \\ -0.236 * * & -0.415 * *\end{array}$

$0.162 *$

0.028

$E U_{h, o}$

$-0.480 * *$

$0.375 * *$

Host/Pull Variables:

$E E_{h}$
$I N C_{h, t-n}$
$I N C_{h, t-n^{2}}$
$E R_{h, t-n}$
$E U_{h}$
$E M P_{h, t-n}$

$-0.165 * *$
$0.082 * *$
0.000
$-0.250 * *$
$0.183 * *$
$3.385 * *$

$-0.327 * *$
$0.309 * *$
-0.014
$0.698 * *$
$0.644 * *$
$1.796 *$

$-0.229 * *$

$-0.121 *$

Origin/Push Variables:

\begin{tabular}{|c|c|c|c|c|c|c|c|c|}
\hline$E E_{o}$ & 0.028 & 0.124 & $* *$ & -0.397 & $* *$ & -0.253 & $* *$ & \\
\hline$I N C_{o, t-n}$ & & -0.078 & $* *$ & 0.181 & $* *$ & -0.106 & $* *$ & $0.226 * *$ \\
\hline$I N C_{o, t-n 2}$ & & 0.009 & $* *$ & -0.014 & $* *$ & 0.012 & $* *$ & $-0.022 * *$ \\
\hline$P O L_{o, t-n}$ & & -0.010 & $* *$ & 0.000 & & -0.011 & $* *$ & $0.010 *$ \\
\hline $\mathrm{CON}_{0, t-n}$ & & 0.038 & $* *$ & 0.000 & & 0.038 & $* *$ & -0.021 \\
\hline \multicolumn{9}{|l|}{ Other Variables: } \\
\hline Inv. Mills Ratio & $1.194 * *$ & 0.028 & & 1.027 & $* *$ & 0.259 & $* *$ & \\
\hline Constant & $-2.518 * *$ & -1.830 & $* *$ & -2.786 & $* *$ & -2.722 & $* *$ & \\
\hline Selected & 21,390 & 21,390 & & 5,278 & & 21,390 & & \\
\hline Observations & 97,346 & 97,346 & & 22,818 & & 97,346 & & \\
\hline$R^{2}$ & 0.774 & 0.786 & & 0.803 & & 0.791 & & \\
\hline
\end{tabular}

Note: ${ }^{* *}=$ significant at $1 \%,{ }^{*}=$ significant at $5 \%$

suggest these countries receive more immigrants, but the effects on emigration are insignificant.

Column (2) of Table 7 shows the regression results for the augmented model that combines equation (3) with equation (4). Augmenting the gravity equation improves the fit, and distance now has the expected negative sign. Shared EU membership leads to more bilateral immigration while shared Schengen Area membership leads to less.

The positive coefficient for the lagged number of migrants (i.e., the stock, not the flow) suggests that the more foreign-born residents a country has, the more immigrants it will soon receive. Regressions include dummy variables for incremental time periods $t$ $>1995, t>2000$, and $t>2005$; these time increments indicate a general deceleration of immigration, independent of the effect of lagged migrants, with exception to the period between 2000 and 2005. Norlander and Sørensen (2018) documented a similar slowdown in the United States. The Great Recession in particular led to a sharp decline for migration into the US, and the recovery afterwards was significantly higher for 
female immigrants (Castañeda and Sørensen 2019). Results here thus extend the pattern internationally.

For the host country, per-capita income has a positive effect on immigration without a significant second-order effect. An overvalued exchange rate - which raises the cost of living in the host country appears to be unattractive to immigrants, suggesting that migration is expected to be permanent. EU membership makes the host country more attractive. Host country employment rates have a positive effect, suggesting rising labor demand matters more than falling labor supply in the host country to create new opportunities for immigrants. Once we consider these other factors, the dummy variable for EE host countries is negative, so EE countries host fewer immigrants than predicted, not more.

For the origin country, per-capita income has a negative effect on emigration, but the second-order effect is diminishing so that the effect reaches zero at an average income of around $\$ 40,000$ USD. Polity has a negative effect, so emigrants are more likely to leave autocracies than democracies, while conflict in the home country appears to significantly increase emigration. These effects aside, the dummy variable for EE origin countries is positive, so they appear to send more emigrants than otherwise predicted.

Column (3) of Table 7 shows the results of a regression for a subsample that is restricted to only $\mathrm{EE}$ countries - as host, origin, or both. While most of the coefficients continue to have the same sign and significance level as in column (2) for the whole sample, a couple differences are notable. First, an overvalued exchange rate in the host country is positively correlated with migration, not negatively. Second, the sign of the income variable switches so that poorer EE countries send fewer emigrants out, not more, and this result is consistent with that of Franc, Časni, and Barišić (2019). Neither autocracy nor conflict in the origin country appears to matter for this subsample. For this subsample, EE countries are still less likely to host immigrants, while EE origin countries also become less likely to send emigrants, not more.

Columns (4.a) and (4.b) report the results of a combined regression in which a regression for EE countries is nested within the greater sample for the entire world. This allows us to test whether the coefficients for EE countries differ significantly from the rest of the world. To do this, the shared, host, and origin effects are specified as:

$$
\alpha\left(X_{h, o, t-n}\right)=\alpha_{0}+\sum\left(\alpha_{i}+\tau_{i} E E_{h, o}\right) X_{i, h, o, t-n}
$$

where the dummy variable $E E$ indicates that either the host or origin country is from Eastern Europe. This makes it simple to test whether the EE difference is statistically significant. Column (4.a) shows the estimates for the whole sample (e.g., the a variables), while column (4.b) shows the difference (or $\Delta$ ) when the host or origin is East European (i.e., the $\tau$ variables). Most differences are significant in Table 7, at least at the 5\% level. For example, the negative effect of SA membership is much reduced, the switch from negative to positive effects for the host country's overvalued currency is very significant, and the positive effect of the host country employment rate is also much reduced. The differences in the income effects for both host and origin are statistically significant.

Table 8 shows the same four regressions for an expanded sample that adds data for both 2015 and 2017 , with the caveat that these additional two years are more likely to be intercensal extrapolations by the UN from pre-2010 trends. This period may also capture changes in immigration patterns due to the Great Recession and the conflicts following the Arab Spring, which many argue helped lead to the Brexit vote and the resurgence of European nationalism. However, the additional data for 2015 and 2017 may have larger estimation errors, as we have discussed.

Comparing Table 8 to Table 7, there are 16 instances in which a significant coefficient becomes insignificant, or vice versa, but does not change sign, and there are four instances in which a sign switches, but in those cases either one or both are insignificant. Finally, there are only four instances in which a coefficient changes a significant sign (e.g., from significantly positive to significantly negative). Two of these are in column (1), the un-augmented gravity model, in which coefficients for both home and origin population become negative. The other two instances are in column (2) for the host country; the signs for both exchange rate overvaluation and Eastern Europe switch from significantly negative to significantly positive. When the estimates of the last decade are included, Eastern Europe hosts more immigrants than otherwise predicted, but this is still largely driven by changes in income and other variables consistent with the 1995-2010 estimates. 
Table 8. Migration Regressions for 1995-2017

Dependent Variable: $\ln \Delta M I G_{h, t-n}$

(1)

Simple

Variables

Gravity Variables:

InPOP
In $P O P_{o, t-t-n}$
$\operatorname{In} D I S_{h, o}$
In $M I G_{h, o}, t-n$
Shared V
$E U_{h, o}$
$S A_{h, o}$
$t>1995$
$t>2000$
$t>2005$
$t>2010$
$t>2015$

$-0.042 \quad * *$
$-0.018 * *$
0.317
1.093 $* *$

(2)

Augmented

(3)

(4.a)

(4.b)

EE Only

World

$\Delta \mathrm{EE}$

Host/Pull Variables

\begin{tabular}{|c|c|c|c|c|c|c|c|c|c|c|}
\hline$E E_{h}$ & 0.145 & $* *$ & 0.084 & $* *$ & -0.136 & & -0.033 & & & \\
\hline$I N C_{h, t-n}$ & & & 0.132 & $* *$ & 0.416 & $* *$ & 0.221 & $* *$ & -0.416 & ** \\
\hline$I N C_{h, t-n^{2}}$ & & & -0.008 & $* *$ & -0.040 & $* *$ & -0.016 & $* *$ & 0.031 & ** \\
\hline$E R_{h, t-n}$ & & & 0.287 & $* *$ & 1.369 & $* *$ & 0.087 & & 1.732 & ** \\
\hline$E U_{h}$ & & & 0.121 & $* *$ & 0.484 & $* *$ & 0.050 & * & 0.382 & ** \\
\hline$E M P_{h, t-n}$ & & & 0.965 & $* *$ & -0.752 & & 1.418 & $* *$ & -0.845 & ** \\
\hline \multicolumn{11}{|c|}{ Origin/Push Variables: } \\
\hline$E E_{o}$ & -0.100 & $* *$ & 0.037 & & -0.392 & $* *$ & -0.370 & $* *$ & & \\
\hline$I N C_{o, t-n}$ & & & -0.074 & $* *$ & 0.114 & $* *$ & -0.083 & $* *$ & 0.112 & ** \\
\hline$I N C_{0, t-n^{2}}$ & & & 0.009 & $* *$ & -0.007 & & 0.010 & $* *$ & -0.009 & $*$ \\
\hline$P O L_{o, t-n}$ & & & -0.007 & $* *$ & 0.006 & & -0.009 & $* *$ & 0.014 & ** \\
\hline $\mathrm{CON}_{0, t-n}$ & & & 0.032 & $* *$ & 0.001 & & 0.031 & $* *$ & -0.013 & \\
\hline \multicolumn{11}{|l|}{ Other Variables: } \\
\hline Inv. Mills Ratio & 1.633 & $* *$ & 0.380 & $* *$ & 1.398 & $* *$ & 0.548 & $* *$ & & \\
\hline Constant & -3.722 & $* *$ & -1.513 & $* *$ & -2.437 & $* *$ & -2.033 & $* *$ & & \\
\hline Selected & 32,876 & & 32,876 & & 8,038 & & 32,876 & & & \\
\hline Observations & 145,706 & & 145,706 & & 34,458 & & 145,706 & & & \\
\hline$R^{2}$ & 0.713 & & 0.784 & & 0.77 & & 0.788 & & & \\
\hline
\end{tabular}

Note: ${ }^{* *}=$ significant at $1 \%,{ }^{*}=$ significant at $5 \%$

\section{CONCLUSION}

More than $17 \%$ of the world's migrants were either born in Eastern Europe or now live there, but the region only accounts for $4.2 \%$ of the world's total population. So is Eastern Europe different in its migration patterns than the rest of the world? The answer appears to be a qualified yes, but not in the way that the above numbers appear to suggest.
This paper uses a UN dataset containing 154 countries from 1990 to 2017 to estimate a gravity equation, which is augmented with pull factors for the host country, push factors from the origin country, and other factors that apply to both. Considering the entire sample, East European countries appear less likely to host immigrants, ceteris paribus, but are more likely to send emigrants abroad. However, this appears to be driven by other ways in which EE countries are 
different in their migration patterns.

For East European migrants, the currency value of the host matters more, suggesting migrants are more likely to be temporary residents that intend to bring home their savings from abroad, or at least that they are motivated by the desire to send remittances back. The host's EU membership matters more, while its employment rate matters less. For the origin country, the effect of income switches. Migrants are less likely to come from poorer countries, and on average do not appear to be driven by autocracy or conflict in the origin countries. Once we adjust for these differences, East European countries appear less likely to host immigrants, and also less likely to send them.

To the extent there is a policy recommendation that comes from this, it is that East European countries should pay special attention to incentives for return migration. Emigrants from this region tend to be relatively young and well educated, and incentives for bringing them back home in time could pay significant future dividends if their home countries could better understand what made them leave in the first place.

This study also opens up several avenues for future research. First, though international migration differs from internal migration as government policy is a much more limiting factor, this study did not consider the effect of immigration policies. Second, do government-funded benefits - such as access to health care, education, or income support - significantly affect the incentive to migrate for East Europeans? Third, if migration is less in this model than we would otherwise expect, why are East Europeans so opposed to it, and supportive of political parties that promise to reduce it? Perhaps the answer comes from the rate at which immigration has changed. In the old regime, prior to the collapse of the Soviet Union and the East European governments aligned with it, immigration was much more restricted and much less desirable even as communist governments espoused international brotherhood. Now, as relatively fragile post-socialist countries assert their national identities, international integration has suddenly brought more open borders.

\section{REFERENCES}

Anderson, J.E. 1979. A theoretical foundation for the gravity equation. The American Economic Review 69 (1): 106-116.

Barry, O. 2019. In Orbán's Hungary, refugees are unwelcome: so are those who try to help. PRI's the World, February 11. https://www.pri.org/stories/2019-02-11/ orban-s-hungary-refugees-are-unwelcome-so-arethose-who-try-help (accessed Jan. 20, 2020).

Bergstrand, J.H. 1985. The gravity equation in international trade: some microeconomic foundations and empirical evidence. The Review of Economics and Statistics 67 (3): 474-481.

Borjas, G.J. 1989. Economic theory and international migration. International Migration Review 23 (3): 457-485.

Castañeda, A.H. and T.A. Sørensen 2019. Changing sex-ratios among immigrant communities in the USA. Journal of Economics, Race, and Policy 2 (1-2): 20-42.

Chapman, A. 2019. Why Poland's populist Law and Justice Party keeps winning. World Politics Review, Sep. 3. https://www.worldpoliticsreview.com/ (accessed Jan. 20, 2020).

Connor, P. and J.M. Krogstad 2018. Many worldwide oppose more migration - both into and out of their countries. Pew Research Center, https://www.pewresearch.org/ fact-tank/2018/ (accessed Jan. 20, 2020).

Crymble, A., A. Dennett, and T. Hitchcock 2018. Modelling regional imbalances in English plebeian migration to late eighteenth-century London. The Economic History Review 71 (3): 747-771.

Efendic, A. 2016. Emigration intentions in a post-conflict environment: evidence from Bosnia and Herzegovina. Post-Communist Economies 28 (3): 335-352.

Esipova, N., A. Pugliese, and J. Ray 2018. Revisiting the most- and least-accepting countries for migrants, Gallup Blog, Dec. 18, https://news.gallup.com/opinion/gallup/245528/revisiting-least-accepting-countries-migrants.aspx (accessed Jan. 20, 2020).

Eurostat 2019. First permits by reason, length of validity and citizenship. Database, https://ec.europa.eu/eurostat/ web/products-datasets/.

Franc, S., A.Č. Časni, and A. Barišić 2019. Determinants of migration following the EU enlargement: a panel data analysis. South East European Journal of Economics and Business 14 (2): 13-22.

Górak-Sosnowska, K. and M. Pachocka 2019. Islamophobia and the quest for European identity in Poland. The Routledge International Handbook of Islamophobia, chap. 18.

Head, K. and J. Ries 1998. Immigration and trade creation: econometric evidence from Canada. Canadian Journal of Economics 31 (1): 47-62.

Heckman, J.J. 1979. Sample selection bias as a specification error. Econometrica 47: 153-161.

Karemera, D., V.I. Oguledo, and B. Davis 2000. A gravity model analysis of international migration to North America. Applied Economics 32 (13): 1745-1755.

Kelly, M. and C. O'Grada 2018. Gravity and migration before railways: Evidence from Parisian prostitutes and revolutionaries. Centre for Economic Policy Research, Discussion Paper DP13046. 
Kennedy, J.F. 1959. A Nation of Immigrants. New York, NY: Anti-defamation League of B'nai B'rith.

Kotorri, M. 2017. The probability of return conditional on migration duration: evidence from Kosovo. South East European Journal of Economics and Business 12 (2): 35-46.

Lewer, J.J. and H. Van den Berg 2008. A gravity model of immigration. Economics Letters 99 (1): 164-167.

Loxha, A. 2019. Do remittances reduce poverty in Kosovo? A counterfactual analysis, South East European Journal of Economics and Business 14 (2): 117-132.

Luqman, A.O., N.A.A. Bakar, and A.A.M. Izraf 2016. The gravity model approach: An application on the ECOWAS trading bloc. South East European Journal of Economics and Business 11 (1): 67-75.

Marshall, M. and T.R. Gurr 2019. Polity IV Dataset, Center for Systemic Peace, https://www.systemicpeace.org/inscrdata.html (accessed Jan. 20, 2020).

Mayda, A.M., G. Peri, and W. Steingress 2018. The political impact of immigration: evidence from the United States. National Bureau of Economic Research, Working Paper 24510.

Minelgaite, I., T.H. Christiansen, and E.S. Kristjánsdóttir 2019. Lithuanian temporary workers in Iceland in another economic boom: expectations and experiences. South East European Journal of Economics and Business 14 (1): 101-114.

Norlander, P. and T.A. Sørensen 2018. 21 st century slowdown: the historic nature of recent declines in the growth of the immigrant population in the United States. Migration Letters 15 (3): 409-422.

Pachocka, M. 2016. Importance of migration and border management issues for the cross-border Cooperation Poland-Belarus-Ukraine in the period 2014-2020 under the European Neighbourhood Instrument. Eurolimes 21: 89-106.

Poot, J., O. Alimi, M.P. Cameron, and D.C. Maré 2016. The gravity model of migration: the successful comeback of an ageing superstar in regional science. Institute of Labor Economics, IZA Discussion Paper 10329.

Santana-Gallego, M. and J.V. Pérez-Rodríguez 2019. International trade, exchange rate regimes, and financial crises. The North American Journal of Economics and Finance 47 (C): 85-95.

Santora, M. 2019. Poland bashes immigrants, but quietly takes Christian ones. The New York Times, Mar. 26.

Sjaastad, L.A. 1962. The costs and returns of human migration. Journal of Political Economy 70 (5): 80-93.

Sulaimanova, B. and A. Bostan 2014. International migration: a panel data analysis of the determinants of emigration from Tajikistan and Kyrgyzstan. Eurasian Journal of Business and Economics 7 (13): 1-9.

Thursby, J.G. and M.C. Thursby 1987. Bilateral trade flows, the Linder hypothesis, and exchange risk. The Review of Economics and Statistics 69 (3): 488-495.

Tinbergen, J. 1962. Shaping the World Economy: Suggestions for an International Economic Policy. New York: Twentieth Century Fund.

UN 2017. International migrant stock: the 2017 revision. United Nations, Department of Economic and Social Affairs, Population Division. https://www.un.org/en/ development/desa/population/migration/data/estimates2/estimates17.asp (accessed Jan. 20, 2020).

Walker, S. 2019. Viktor Orbán trumpets Hungary's 'procreation, not immigration' policy. The Guardian, Sep. 6.

World Bank 2019. World Development Indicators Databank, https://databank.worldbank.org (accessed Jan. 20, 2020).

White, A. 2018. The impact of migration into Poland by non-Poles. In White, A., I. Grabowska, P. Kaczmarczyk, and K. Slany, eds. The Impact of Migration on Poland: EU Mobility and Social Change: 213-226. University College London Press.

Zipf, G.K. 1949. Human Behavior and the Principle of Least Effort. Cambridge, MA: Addison- Wesley Press. 